\title{
Teori Demokrasi dalam Wacana Ketatanegaraan Perspektif Pemikiran Hans Kelsen
}

\author{
HM. Thalhah \\ Jl. Gajah Mada No. 212-214 Bojonegoro Jawa Timur
}

\begin{abstract}
In Hans Kelsen opinion, one of the essences of democracy is the possibility for compromising various aspirations with regard to the foundation of a state. The principle of compromise is the settlement of a conflict via certain procedure which is not fully in favor of a party and ignoring the rests. By this compromise, democracy performs as an approach in the process of achieving the hope perfectly.
\end{abstract}

Keywords: the theory of democracy, aspiration of the majority, aspiration of the minority, compromise.

\section{Pendahuluan}

Demokrasi dipahami sebagai sebuah ruang lingkup yang sangat luas. Apapun bentuknya, fenomena demokrasi sangat menarik untuk dibicarakan. Apalagi jika dikaitkan dengan kenyataan, bahwa negara Indonesia merupakan negara yang masih menjadikan proses demokratisasi sebagai sebuah tumpuan. Secara substansial, demokrasi tidak akan berjalan dengan efektif tanpa berkembangnya pengorganisasian internal partai, lembagalembaga pemerintahan, maupun perkumpulan-perkumpulan masyarakat.

Kelestarian demokrasi memerlukan rakyat yang bersepakat mengenai makna demokrasi, yang paham akan bekerjanya demokrasi dan kegunaannya bagi kehidupan mereka. Demokrasi yang kuat bersumber pada kehendak rakyat dan bertujuan untuk mencapai kebaikan atau kemaslahatan bersama. Oleh karena itu, demokrasi mesti berkaitan dengan persoalan perwakilan kehendak rakyat itu. ${ }^{1}$ Dalam bingkai teori politik,

\footnotetext{
${ }^{1}$ Mochtar Mas'oed, Negara, Kapital dan Demokrasi, cetakan kedua, Pustaka Pelajar, Yogyakarta, 1999, hlm 6.
} 
demokrasi lebih menekankan pada unsur masyarakat sebagai sebuah variabel. $^{2}$

Terlepas dari pengertian demokrasi dengan beberapa pra syarat seperti di atas, ada banyak pemikir, khususnya di bidang politik, yang menggunakan wacana demokrasi sebagai bahan perbincangan. Sejauh ini, wacana demokrasi hanya berkembang dalam tataran kurang fungsional. Di samping itu, banyak pemikir demokrasi yang salah memisahkan diri dengan wacana hukum ketatanegaraan, padahal, di satu sisi, antara teori demokrasi dengan teori ketatanegaraan banyak sangkut pautnya. Dalam konteks ini terutama jika menyangkut tatanan yang berkaitan dengan kelembagaan negara sebagai sebuah representasi kehendak rakyat.

Salah satu pemikir yang mencoba menggabungkan kedua faktor tersebut adalah Hans Kelsen. Secara garis besar, pemikiran Hans Kelsen mengenai teori hukum sangatlah lengkap. Banyak yang tak menyangka bahwa Hans Kelsen ternyata juga mempunyai teori pada bidang demokrasi. Tak hanya berkutat pada konsep negara semata, pemikiran Hans Kelsen bergerak maju ke arah perkembangan yang lebih dinamis. Jika kita menilik pemikiran Hans Kelsen secara seksama, maka akan kita temukan konsep hukum yang lengkap sekaligus praktis. Dengan kata lain, kelebihan Hans Kelsen dalam menata teori hukum ternyata juga didukung oleh penerapan teori yang dimaksud. Persoalan yang menarik untuk dikaji adalah bagaimana pemikiran Hans Kelsen tentang teori demokrasi dalam wacana ketatanegaraan.

\section{Dasar Teori Demokrasi Versi Hans Kelsen}

Mengutip teori Jean Jaques Rousseau, demokrasi adalah sebuah tahapan atau sebuah proses yang harus dilalui oleh sebuah negara untuk

${ }^{2}$ Variabel ini yang banyak dipakai oleh ilmuwan politik semenjak tahun 1950, terutama bagi para ilmuwan politik yang sedang mempelajari negara-negara yang baru saja merdeka. Variabel inilah yang kemudian dipatahkan oleh Samuel Huntington. Menurutnya, variabel masyarakat dalam mendukung gagasan tentang demokrasi tidak sepenuhnya benar. Di negara-negara yang baru saja merdeka tersebut, ternyata masyarakat justru kehilangan kekuatannya. Karena itu kemudian para analisa politik kemudian berpindah ke sisi negara dalam melakukan kajian tentang demokrasi. Menurut hemat penulis, hal inilah yang kemudian mendekatkan teori politik dengan teori hukum murni. Meskipun begitu, penulis menilai bahwa variabel masyarakat sangat penting artinya bagi perkembangan demokrasi sebuah negara. 
mendapatkan kesejahteraan. Pernyataan Rousseau ini seakan mengatakan, bahwa demokrasi bagi sebuah negara adalah sebuah pembelajaran menuju ke arah perkembangan ketatanegaraan yang sempurna. Padahal disadari oleh Rousseau, bahwa kesempurnaan bukanlah milik manusia. Oleh karenanya, yang menjadi ukuran ada tidaknya sebuah demokrasi dalam sebuah negara bukan ditentukan oleh tujuan akhir, melainkan lebih melihat pada fakta tahapan yang ada. Demokrasi akan berjalan sesuai dengan perkembangan zaman dan akan sangat dipengaruhi oleh faktor budaya sebuah negara. Dengan begitu Rousseau seolah ingin mengatakan bahwa jika menempatkan demokrasi secara kaku dan ideal, tidak akan pernah ada demokrasi yang nyata dan tidak akan pernah ada demokrasi. ${ }^{3}$

Hal inilah yang juga disadari oleh Hans Kelsen. Uraiannya tentang demokrasi menjadi lebih tertata dan terstruktur. Ini untuk membuktikan, bahwa demokrasi adalah sebuah proses yang berkelanjutan menuju kesempurnaan. Awal dari datangnya ide demokrasi menurut Hans Kelsen adalah adanya ide kebebasan yang berada dalam benak manusia. Pertama kali, kosakata "kebebasan" dinilai sebagai sesuatu yang negatif. Pengertian "kebebasan" semula dianggap bebas dari ikatan-ikatan atau ketiadaan terhadap segala ikatan, ketiadaan terhadap segala kewajiban. Namun, hal inilah yang ditolak oleh Hans Kelsen. Pasalnya, ketika manusia berada dalam konstruksi kemasyarakatan, maka ide "kebebasan" tidak bisa lagi dinilai secara sederhana, tidak lagi semata-mata bebas dari ikatan, namun ide "kebebasan" dianalogikan menjadi prinsip penentuan kehendak sendiri. Inilah yang kemudian menjadi dasar pemikiran Hans Kelsen mengenai demokrasi. ${ }^{4}$

Pendapat Hans Kelsen mengenai ide "kebebasan" dalam konteks kehidupan bermasyarakat ini sejalan dengan pemikiran cendekiawan muslim, Abu Nashar bin Mohammad bin Mohammad bin Tharkam bin Unzalagh, atau yang lebih dikenal dengan sebutan Farabi. Bagi Farabi, kehidupan manusia tidak bisa lepas dari masyarakat karena pada hakekatnya manusia adalah makhluk sosial. Hakekat ini merupakan

${ }^{3}$ Ini adalah kesimpulan penulis berdasarkan pendapat yang dikemukakan oleh Jean Jaques Rouseau. Untuk lebih jelasnya bisa dilihat dalam Jean Jacques Rousseau, Du Contract Social (Perjanjian Sosial), Cetakan Pertama, Visimedia, Jakarta, 2007, hlm 113.

${ }^{4}$ Hans Kelsen, Teori Umum Tentang Hukum dan Negara, Cetakan pertama, Penerbit Nuansa dan penerbit Nusamedia, Bandung, 2006, hlm 404. 
sebuah kecenderungan yang alami. Adapun kecenderungan untuk hidup bermasyarakat tidak semata-mata untuk memenuhi kebutuhan pokok, akan tetapi juga menghasilkan kelengkapan hidup yang akan memberikan kepada manusia kebahagiaan, tidak saja secara material, namun juga spiritual. Salah satu kelengkapan hidup adalah timbulnya bermacam pemikiran atau ide. Ini bisa diartikan bahwa ide kebebasan dalam versi Farabi merupakan sebuah kecenderungan alami, dengan tujuan kebahagiaan hidup. ${ }^{5}$

Dalam masyarakat, sudah barang tentu akan terbentuk pemilahanpemilahan ide atau kehendak. Berbagai pendapat mengenai sebuah persoalan akan muncul secara acak. Dari titik inilah munculnya pola kepentingan yang berujung pada adanya suara mayoritas dan suara minoritas, yang masing-masing mempunyai hak dan kewajiban. Dalam pandangan Hans Kelsen, suara mayoritas tidak melahirkan dominasi absolut atau dengan kata lain, dalam bahasa Hans Kelsen, adalah kediktatoran mayoritas atas minoritas. Prinsip mayoritas dalam masyarakat demokratis, hanya dapat dijalankan jika segenap warga masyarakat dalam sebuah negara diperbolehkan turut serta dalam pembentukan tatanan hukum. Inilah yang kemudian melahirkan istilah kompromi. ${ }^{6}$

\section{Demokrasi dan Kompromi Dalam Pemikiran Hans Kelsen}

Bertemunya suara mayoritas dan suara minoritas tentunya menghasilkan kompromi. Menurut Hans Kelsen, salah satu esensi demokrasi terletak pada ada tidaknya sebuah kompromi yang menyatukan perbedaan pendapat untuk menentukan sebuah tatanan bagi landasan sebuah negara. Prinsip kompromi adalah penyelesaian sebuah masalah

${ }^{5}$ Munawir Sjadzali, Islam dan Tata Negara; Ajaran, Sejarah, dan Pemikiran, Edisi Kelima, UI Press, Jakarta, 1993, hlm. 51. Lebih lanjut Farabi mengemukakan bahwa terbentuknya sebuah masyarakat akan sangat berbeda antara satu sama lain. Perbedaan itu akan sangat bergantung kepada faktor iklim dan lingkungan tempat tinggal dimana masyarakat tersebut tinggal. Faktor kewilayahan inilah yang kemudian membentuk watak, pola pikir, perilaku, orientasi atau kecenderungan dan adat kebiasaan, termasuk di dalamnya adalah pemikiran. Dalam konteks ini, bisa dipahami bahwa Farabi juga memilliki pemahaman yang sama terhadap tahapan atau proses kehidupan manusia, termasuk pola pikir, yang pada nantinya akan membentuk wacana tentang masyarakat, pemerintahan dan demokrasi.

${ }^{6}$ Hans Kelsen, Op.Cit, hlm 407. 
(konflik) melalui suatu norma yang tidak seluruhnya sesuai dengan kepentingan-kepentingan dari salah satu pihak, tidak juga seluruhnya bertentangan dengan kepentingan-kepentingan pihak lain. ${ }^{7}$

Dengan adanya kecenderungan seperti itu, demokrasi merupakan suatu pendekatan ke arah cita-cita penentuan kehendak sendiri secara sempurna. Sejalan dengan hal tersebut, pembahasan yang terjadi di antara mayoritas dan minoritas terus menerus dilakukan agar terjadi sebuah kesepakatan bersama dan menjadi pegangan bagi masyarakat dalam melakukan kegiatannya.

Pembahasan sebuah masalah tidak terbatas dalam parlemen semata, tetapi sebagian besar juga terjadi di lembaga-lembaga politik, di dalam surat kabar, buku, dan sarana-sarana pendapat umum yang lain. Sebuah negara berciri demokrasi mempunyai sarana-sarana yang luas terhadap keberadaan pendapat umum. Menurut Hans Kelsen, pendapat umum hanya dapat muncul jika kebebasan intelektual, kebebasan berbicara, kebebasan pers, dan kebebasan beragama dijamin. ${ }^{8}$

Jaminan kebebasan beragama dalam kehidupan bernegara tidak hanya dijamin keberlangsungannya, tetapi di jaga dan dipupuk agar berdampingan dengan agama yang menjadi mayoritas pada sebuah negara. Selain diakui oleh Hans Kelsen, pengakuan terhadap kebebasan beragam juga dijamin oleh pemikir Islam lainnya, yaitu Abdul Qodir Jaelani. Masalah agama dan keyakinan tidak boleh berada dalam ruang lingkup pemaksaan, baik pemaksaan yang timbul dari daya tarik ekonomi atau bahkan daya tarik seks. Untuk menentukan pilihan dalam konteks agama dan keyakinan, sepenuhnya diserahkan kepada individu yang bersangkutan. ${ }^{9}$

Dari semua yang ditawarkan oleh Hans Kelsen, bahwa kompromi menjadi sebuah syarat utama dalam penentuan apakah sebuah negara menganut prinsip demokrasi ataukah tidak sama sekali. Tentu saja, dalam prinsip demokrasi sangat bergantung pada budaya, dan adat istiadat setempat. Hal itu disadari betul oleh Hans Kelsen, oleh karenanya ia menuturkan bahwa prinsip demokrasi sebuah negara tidak bisa dijadikan patokan bagi negara lain. Tergantung pada banyak aspek dan keberadaan lingkungan yang melingkupinya. Dewasa ini, banyak sekali varian

\footnotetext{
${ }^{7}$ Ibid

${ }^{8}$ Ibid

${ }_{9}^{9}$ Abdul Qodir Jaelani, Negara Ideal Menurut Konsepsi Islam, Karya Baru Press, Surabaya, 1995, hlm 252.
} 
demokrasi yang terjadi pada sebuah negara. Varian ini menyimpulkan, bahwa keberadaan budaya demokrasi tidak terjadi begitu saja, namun melalui proses. Proses awalnya, dalam konsepsi Hans Kelsen, adalah adanya kompromi yang sehat yang terjadi di antara kehendak mayoritas dan kehendak minoritas. Hal tersebut tidak hanya terbentuk pada parlemen semata, tetapi juga melembaga dalam kehidupan politik yang lain.

Ada sebuah pegangan dalam memahami sikap Hans Kelsen mengenai negara dengan bercirikan prinsip demokrasi. Di antaranya adalah:

1. Adanya kehendak mayoritas dan kehendak minoritas

2. Kehendak mayoritas tidak bisa menjadi dominasi absolut

3. Adanya kompromi di antara kehendak mayoritas dengan kehendak minoritas dalam menyikapi sebuah permasalahan dan dalam pembentukan sebuah tatatan.

4. Tidak ada pemaksaan dalam beragama dan berkeyakinan

5. Terdapat kebebasan berbicara, kebebasan pers, dan pendapat untuk mengemukakan pendapat dijamin keberadaannya, baik melalui konstitusi ataupun melalui kesepakatan adat yang terjadi di sebuah negara.

6. Kompromi yang sehat menjadikan tidak diketemukannya perbenturan kepentingan antara kehendak mayoritas dan kehendak minoritas yang akan biasanya akan berbuah pada anarki.

\section{Prinsip Keterwakilan Masyarakat Dalam Lembaga Politik}

Tipe demokrasi yang ideal diwujudkan dalam derajad yang berbedabeda. Melalui konstitusi yang berbeda-beda pula. Demokrasi langsung adalah demokrasi yang mempunyai derajad paling tinggi. Demokrasi langsung dapat ditandai dengan fakta, bahwa pembuat peraturan, dan juga fungsi eksekutif dan fungsi legislatif, dilakukan oleh masyarakat di dalam pertemuan akbar atau sebuah pertemuan umum. Pelaksanaan semacam ini hanya mungkin terjadi di dalam masyarakat-masyarakat kecil dan di bawah kondisi-kondisi sosial yang sederhana. Oleh karenanya, dalam pendapat Hans Kelsen dan sebagian besar pemikir politik dan ketatanegaraan lainnya, demokrasi langsung semacam ini tidak lagi mendapatkan tempat dalam konsep demokrasi modern yang saat ini sedang diwacanakan oleh banyak pemerintahan di dunia.

Hal yang paling mungkin terjadi adalah suatu demokrasi dimana fungsi legislatif dijalankan oleh parlemen yang dipilih oleh rakyat, dan 
fungsi eksekutif dan yudikatif juga dijalankan melalui pemilihan umum yang dijamin keabsahannya. Pada kondisi ini, Hans Kelsen menyatakan pendapatnya bahwa suatu pemerintahan adalah sebuah "perwakilan" karena sepanjang pejabat-pejabatnya dipilih oleh rakyat, maka pejabat tersebut bertanggungjawab penuh terhadap pemilihnya. Jika kemudian pemerintahan tidak bisa bertanggungjawab penuh terhadap pemilihnya, maka hal ini tidak bisa disebut sebagai "perwakilan yang sesungguhnya" ${ }^{10}$

Dalam demokrasi modern, secara mencengangkan, Hans Kelsen berpendapat bahwa apa yang terjadi dewasa ini di negara-negara yang mengatasnamakan negara demokrasi, ternyata tidak sepenuhnya memahami proses keterwakilan ini. Prinsip keterwakilan yang dipahami oleh Hans Kelsen ternyata berorientasi pada ada tidaknya proses pertanggungjawabannya terhadap pemilih. Ini artinya, demokrasi dalam konteks perwakilan mengharuskan adanya pertanggungjawaban yang besar, terutama secara moral, kepada para pemilihnya, dan bukan pertanggungjawaban terhadap partai politik yang mengusungnya.

Secara umum, pendapat-pendapat yang dikemukakan oleh Hans Kelsen banyak sekali berdasar pada filsafat Plato dan Aristoteles dan juga beberapa pemikir lain yang hidup pada zaman Yunani kuno. Ada beberapa alasan mengapa bangsa Yunani bisa memberikan kontribusi pemikiran terhadap beberapa teori hukum yang fundamental terhadap perkembangan hukum ke depan. Kecenderungan-kecenderungan untuk berpikir spekulatif serta persepsi intelektualnya untuk menyadari adanya kehidupan manusia dan konflik-konflik dalam kehidupan dunia ini, seperti terlihat dalam karya-karya filsafat dan kesusasteraannya. ${ }^{11}$

Perkembangan Polis (negara kota pada masa bangsa Yunani), membuat bangsa Yunani lebih tajam dalam memandang persoalan hukum. Banyaknya kekacauan, konflik-konflik, pergantian pemerintahan yang begitu sering terjadi, serta masa-masa tirani, membuat bangsa Yunani dapat memberikan bahan yang banyak sekali bagi pemikiran hukum yang sifatnya spekulatif mengenai persoalan hukum dan masyarakat. Secara fundamental, hal tersebut membuat banyak sekali sumbangsih bangsa Yunani terhadap perkembangan hukum, terutama yang berhubungan dengan masyarakat atau publik.

\footnotetext{
${ }^{10}$ Hans Kelsen, Op.Cit. hlm 409.

${ }^{11}$ Satjipto Rahardjo, Ilmu Hukum, cetakan ke lima, Citra Aditya Bakti, Bandung, 2000, hlm. 256
} 
Harus diakui bahwa pemikiran Plato dan Aristoteles menjadi bahan referensi bagi dunia perkembangan hukum. Plato memberikan sumbangan pemikiran dalam dua bukunya yang begitu fenomenal, masing-masing The Republic dan The Laws. Dalam The Republic, Plato memberikan sebuah solusi atas pertentangan-pertentangan yang terjadi di dalam masyarakat. Penyelesaian atau solusinya berada pada kaum cendekiawan yang mengerti hukum, yang oleh Plato disebut sebagai hakim.

Pada buku The Laws, Plato kemudian memberikan sebuah jawaban terhadap permasalahan hukum yang sebelumnya ada pada buku The Republic. Konsep "negara hukum" menjadi sebuah pertimbangan dalam menyatukan visi dan misi masyarakat terhadap persoalan hukum. Dalam karyanya ini, Plato tidak lagi memberikan konsep negara yang hanya diperintah oleh kekuasaan serta orang-orang yang bebas. Keadilan harus dijalankan melalui "norma-norma yang tertulis". Negara harus dijalankan oleh penguasa negara yang tidak membeda-bedakan orang atau masyarakat.

Pemikiran Plato ini kemudian disempurnakan oleh sang murid, yaitu Aristoteles. Aristoteles melakukan pembedaan yang esensial terhadap konsep hukum tentang apa yang dinamakan sebagai keadilan distributif dan keadilan korektif. Bagi Aristoteles, keadilan distributif adalah konsep keadilan menyangkut soal pembagian barang-barang dan kehormatan kepada masing-masing orang sesuai dengan tempatnya di masyarakat. Ia juga sepakat dengan Plato, bahwa kedudukan semua orang di muka hukum adalah sama dan seimbang.

Sedangkan keadilan korektif, menurut Aristoteles, dalam menjalankan hukum, harus ada standar tunggal dan sama yang sifatnya umum, sebagai sebuah konsekuensi dari suatu tindakan yang dilakukan orang dalam hubungannya dengan orang lain di sekitarnya. Standar tersebut harus seimbang dan diterapkan tanpa melihat orang. Standar yang digunakan juga harus obyektif.

Keberadaan hukum merupakan sebuah prasyarat demi adanya keteraturan kehidupan dalam bermasyarakat. Dalam perkembangannya, hukum tidak hanya mengatur tingkah laku yang sudah ada dalam masyarakat dan mempertahankan kebiasaan yang telah ada. Lebih dari itu semua, hukum telah mengarah pada suatu alat atau sarana. Selain itu pendapat yang mengatakan bahwa hukum merupakan sebuah ekspresi atau kehendak yang terwujud dalam masyarakat, juga dapat dipergunakan sebagai definisi hukum. 


\section{Penutup}

Berdasarkan uraian di atas dapat disimpulkan bahwa, negara berdasarkan prinsip demokrasi, menurut Hans Kelsen memerlukan rakyat yang bersepakat mengenai makna demokrasi, yang paham akan bekerjanya demokrasi dan kegunaannya bagi kehidupan mereka.

Demokrasi yang kuat bersumber pada kehendak rakyat dan betujuan untuk mencapai kebaikan atau kemaslahatan bersama. Oleh karena itu, demokrasi mesti berkaitan dengan persoalan perwakilan kehendak rakyat. Di samping itu, demokrasi berarti tersedianya prinsip kebebasan beragama, kebebasan berpendapat dan kebebasan berserikat.

Demokrasi memuat konsepsi kompromi, yaitu adalah penyelesaian sebuah masalah (konflik) melalui suatu norma yang tidak seluruhnya sesuai dengan kepentingan-kepentingan dari salah satu pihak, tidak juga seluruhnya bertentangan dengan kepentingan-kepentingan pihak lain.

Prinsip keterwakilan yang dipahami oleh Hans Kelsen ternyata berorientasi pada ada tidaknya proses pertanggungjawabannya terhadap pemilih. Ini artinya, demokrasi dalam konteks perwakilan mengharuskan adanya pertanggungjawaban yang besar, utamanya secara moral, kepada para pemilihnya, dan bukan pertanggungjawaban terhadap partai politik.

Sosialisasi terhadap tumbuh dan berkembangnya pemahaman demokrasi perlu dilakukan terus kepada masyarakat, khususnya bagi masyarakat yang tinggal di negara-negara berkembang, dimana tata lakasana proses transformasi informasi masih menjadi kendala yang sangat besar.

Pengakuan kebebasan beragama dan kebebasan berpendapat dalam sebuah negara demokrasi menjadi sebuah faktor yang sangat penting. Pemahaman mengenai hal ini perlu dilakukan oleh negara-negara yang memaklumatkan dirinya sebagai negara yang berdasar agama dan negara dengan bentuk pementintahan monarkhi.

Dalam wacana yang dikembangkan oleh Hans Kelsen, permasalahan proses demokrasi tidak terletak pada proses sehat tidaknya sebuah partai politik, akan tetapi lebih kepada arah pertanggungjawaban pemerintah atau lembaga legislatif dan lembaga yudikatif terhadap pemilihnya.

\section{Daftar Pustaka}

Abdul Qodir Jaelani, Negara Ideal Menurut Konsepsi Islam, Karya Baru Press, Surabaya, 1995 
Arbi Sanit, Partai, Pemilu dan Demokrasi, Pustaka Pelajar, Yogyakarta, 1997

Hans Kelsen, Teori Umum Tentang Hukum dan Negara, Cetakan pertama,

Penerbit Nuansa dan penerbit Nusamedia, Bandung, 2006

Jean Jacques Rousseau, Du Contract Social (Perjanjian Sosial), Cetakan Pertama, Visimedia, Jakarta, 2007

Miriam Budiardjo, Dasar-Dasar Ilmu Politik, Cetakan. Kesepuluh, Gramedia, Jakarta, 1986

Mochtar Mas'oed, Negara, Kapital dan Demokrasi, cetakan kedua, Pustaka Pelajar, Yogyakarta, 1999

Munawir Sjadzali, Islam dan Tata Negara; Ajaran, Sejarah, dan Pemikiran, Edisi Kelima, UI Press, Jakarta, 1993

Nezar Patria dan Andi Arief, Antonio Gramsci; Negara dan Hegemoni, Pustaka Pelajar, Yogyakarta, 1999

Ronald H. Chilcote, Teori Perbandingan Politik; Penelusuran Paradigma, Cetakan pertama, Rajawali Press, Jakarta, 2003

Satjipto Rahardjo, Ilmu Hukum, cetakan ke lima, Citra Aditya Bakti, Bandung, 2000

Soehino, S.H, Ilmu Negara, Cetakan Kedua, Liberty, Yogyakarta, 2002 